\title{
MEDICAL RECORDS OF DARTMOUTH,
}

\author{
I 425-I 887 \\ $A$ contribution to the history of medical practice
}

by

\section{R. M. S. McGONAGHEY}

ThIs essay is an attempt to show how the problems of sickness were met in a small sea-port town far from the centre of government. Though of necessity the narrative must be disjointed, for only fragments of information can be found in the records, there is perhaps some value to be gained from the study of a place where change has always come slowly, and in which the population has remained for the most part relatively static. Local history has always been the plaything of the industrious amateur who, often skilled in the recording of local events and local topography, is not well equipped to portray the social life of the people of whom he writes. Perhaps the greatest service that the local historian can make to the study of history is in the description of the effect of the laws and regulations made by the distant central government on the lives and doings of the people. By studying the impact of government on a social unit which has a continuity of existence, a better picture of the results of legislation may be obtained than by taking isolated occurrences from distant, unconnected places.

Small towns have their history, and a study of their records can often resolve doubts and problems. In this essay an attempt is made to describe the kind of medical attention which could have been obtained by the inhabitants of the small port of Dartmouth in Devon. Dartmouth first came into prominence in the twelfth century when the upper reaches of the tidal waters of the river Dart began to silt up, so that the larger vessels then becoming more commonly used were unable to navigate easily upstream so far as the ancient town of Totnes. The safe harbourage made it a convenient point of departure for military expeditions and for pilgrimages. Thus the town early achieved corporate life.

Dartmouth straggles up from the west bank of the river to a considerable height. John Prince ${ }^{1}$ in his Worthies of Devon described it thus:

A large populous town, situate on the south side of a very steep hill, which runneth east to west a considerable length, of near a mile, whereby the houses, as you pass on the water, seem pensil, and to hang along in rows, like gally-pots in an apothecary's shop; for so high and steep is it, that you go from the lower to the higher part thereof by stairs; and from the bottom to the top, requires no less, in some places many more, than an hundred.

Though during the last hundred years some of these declivities have been eased, many houses are approached only by steps, and in spite of its natural beauty the family doctors find their work hard on that account. Indeed, the 


\section{R. M. S. McConaghey}

first to consider it worthwhile to launch out into a carriage is still remembered by the old inhabitants.

The pre-reformation records of Dartmouth are more complete than those of most other towns. From them we might expect to find what medical aid the inhabitants could call upon. There were no monasteries nearer than Tor Abbey and Cornworthy, twelve and eight miles away. At Slapton, six miles distant, was a collegiate church with four brethren, but there is no evidence of any link between the town and the priory. 'The belief that monks and friars were the doctors of the Middle Ages is a gigantic delusion' wrote G. G. Coulton, ${ }^{2}$ and the records of Dartmouth clearly bear out this statement. But a search of the medieval records of the town reveals no evidence of physician, surgeon or apothecary. Richard Leche of Cornworthy witnessed a deed bequeathing lands to the church ( $14 \mathrm{II}),{ }^{3}$ and master John the Leche received $6 d$. for plastering a floor in 1529,4 -hardly the work of a medical man. The only mention of 'leche craft' is in the playnt of trespass by Robert Savery ( 1501 ), ${ }^{5}$ who claims damages of Thomas Harry for wounding his horse whilst shoeing it, by which

ye said hors ys utterly lost and destroyed to ye grete hurt and damage of ye forsaid Robert Savery XXXs. st. by syds hys grete charge and cost of his leche craft which amonteth to XIIIs.

In the proceedings of the mayor's court, however, there are frequent references to barbers and, as we shall see, one entry gives incontrovertible evidence that one at least of these barbers practised as a surgeon in the town.

Dartmouth in the Middle Ages was a town of some importance. It imported considerable quantities of wine and other goods from Normandy. It was used by several rulers as a port of assembly for campaigns on the Continent. Richard I assembled his fleet there for the third Crusade. Edward III collected there the larger part of the fleet which he sent to the Siege of Calais, and increasingly as the period advanced, the borough became busy as an embarkation point for pilgrims departing for the Continent. The citizens of the borough were early known to be of an independent and inflammable nature. They would not readily brook interference from others. Thus they had joined in the reign of Edward III with the seamen of Portsmouth in sweeping the French fleet from the Channel. In the light of this, it comes as no surprise that one of the earliest recorded barbers of Dartmouth was a somewhat bellicose spirit. On 22 July 1433, Henry VI ordered justices of the county to form a Commission,

to enquire into an attack made at Dartmouth upon Baldewin Fulleford, escheater for Devon his clerks and servants, by a certain Henry Hert of Totnesse marchannt and Richard Carsewell of Clyfton Dertemouthe Hardenesse* barbour, and malefactors and disturbers of the peace to the number of forty persons armed and arrayed as if for war and insurrection and so struck wounded and ill treated Baldwin his clerks and servants so that they could hardly get away alive-a pernicious example to other malefactors. ${ }^{\circ}$

We do not know what gave rise to this affray but it is satisfactory to note that on 20 December of the same year, the same Baldewin Fulleford Esquire remitted all personal actions against seventy-three persons, including Richard Carswell.?

* Clifton Dartmouth Hardness remains the full official title of the borough. 


\section{Medical Records of Dartmouth, 1425-1887}

Only eleven days before the Commission was appointed to go into Carswell's ill-deeds he himself was appointed to a Commission

to appraise the wines and other merchandise of the King's Spanish enemies, which had been captured in a crayer off Lesclus, called 'Manequeneth', Copyn la Clerk, master, and brought to Dartmouth. ${ }^{8}$

The first record of Richard Carswell (Kerswell) is in 1425 when he, with others, granted a tenement to William Glover and Johanna his wife. ${ }^{9}$ There are, after these, sundry records of his signature to deeds, until in I440-I he became mayor. ${ }^{10}$

Carswell seems to have given up barbering for the more lucrative one of merchant. In April, 1446 he sailed with others

in a barge laden with divers merchandise which was overtaken and captured by a ship off Bilbawe Byskey called 'Bark'. They waited nine months and more in Spain for the restitution promised by the Court, but obtained no redress.

All ships and merchandize of Castile in England were ordered to be arrested until restitution had been made. ${ }^{11} \mathrm{He}$ later returned to Dartmouth to become bailiff (1447).

A more senior contemporary of Carswell was William Greys or Grys, a barber whose name appears as a witness to various deeds, 1409-20.12 In 1496 we learn of another barber of Dartmouth, a man of whose character we may judge from the few records which have come down to us. He is John Cole who lived in a tenement in which Thomas Dowrysh enfoeffed John Holman. ${ }^{13}$ Gole was not as careful over the upkeep of his domain as would be expected of a man of his social standing, for in that year the Mayor's Court indicted him in 'that a certain "Thrang" (drain) between Richard Mor (iiiid.) and Agneta William (iiiid.) was in danger. They and John Knowllys, John Cole Barber are indicted'.$^{13}$ Two years later the jury of the Mayor's Court found that John Cole had 'one frownt ruinous and weak'. ${ }^{14}$ John Cole was not always at fault over this, and himself had difficulties to contend with. Thus, in 1505 he

compleynyth upon John Wellys in a pleynt of dett and demandith of hym XVIs. VIIId. st. which he awt and wrongfully withholdith for as much as the said defendant desirid and prayed the said pl. to hele and cur these cures folowing that is to say oone of the brestis of the wif of the said def. wherfor he shold have for his labor IIIs. IIIId. And also the said pl. shold hele and cur the kne of oone of the leggis of the said def. Wherefor he shold have for his labor and cur XIIIs. IIII $d$., sum total XVIs. VIIId. etc., ${ }^{15}$

History does not relate the outcome. It might be assumed that he failed in his claim, for later in the same year the jury of the Mayor's Court found that the gutter between John Knowllys and John Cole barber was a nuisance. ${ }^{16}$ We do not know who this John Cole was, but it seems that he was a man of substance and it is fair to assume that Cole, although designated barber, was in fact a general practitioner of the town in that he was employed in treating a disease of the breast and a defective knee, for which he had to sue for payment. This failure to pay for services rendered would be taken by many modern general practitioners as further evidence of the standing of Cole as a medical practitioner. 


\section{R. M. S. McConaghey}

In 1507 , Cole became involved in another law suit which was tried before the Mayor's Court. ${ }^{17}$ On this occasion he pleaded through an attorney. It was stated that one Richard House came into the garden of Cole with eight swine, who ate his beans and destroyed his beds which were sown with certain seeds and turned up his leeks and all other herbs which were his 'tresour and vyand'. Two further trespasses were alleged and the damage claimed was forty shillings. Richard House brought a counter suit against John Cole that

he thies vii yeres past a yenst the will and licence of the said pl. as well in blowyng tyme of his corne and repyng of the same as when he hath haynyd his medawes for his lyving the said John Cole and his servannts brekith down his heggs and goith through the corne and medaw of the said pl. and distroith the corne and medaw that they passe over and levyth open the gates where the said corne and medaw groith that diverse bests as well swyne as other catell goeth into the said corne and ther ete and distrie moche of the said corn and medaw to liiis. iiid. damags.

This case was sent to arbitration. Let us hope that John Cole, whom the jury of the Mayor's Court found on the 30 September 1502 to have 'assaulted Thomas Sherman with I bochers ax', was not the same person. On that same day Johanna, wife of William Frannces, leche was adjudged 'a common listener at windows' ${ }^{17 a}$ In May of the same year he had with divers others, been found to 'annoy the people of the Lord King by exhibiting de Cratell [? de Cartell = barrels or casks] on the King's way in le Ford Lane, and was fined vid. for the festival of the Birth of St. John';18 and on the same day that his wife appeared before the Court, he was found to annoy people by depositing 'robell' in Ford Lane. Seventeen days later ( 17 October 1502 ) he makes his last ignoble appearance in the records. The bailiff attached the goods of William Frannces on a plea of debt and delivered the same in full Court to William Dougty. The inventory of these goods is interesting:

a woman gown of Blewe price ixs. a tavy gown for a man price viiis. anoder Tavy Gown price xiis. a gredyeryn and a brandyse price viiid. xviiil. of feders price vis. iid. dobeletts of Stamy one blewe anoder blak price iiis. an old carpet of yrlond price viiid. item a stayned cloth price $\mathrm{vd}$. I hamer price $\mathrm{v} d$. a jenet price $\mathrm{vd.}$ a nadys (adze) price iiiid. a brode ax price $\mathrm{xd}$. a small hammer iiid. ${ }^{10}$

Throughout the records of the mayor's courts in the early fifteenth century are records of fines imposed on those who deposited rubbish in the highway or allowed their drains to become defective or their overhanging eaves to become dangerous. These entries give the impression that the cleanliness and orderliness of the town was well cared for.

Another leche called Gillam or perhaps the same William Frannces (it is not easy to say) was sued by William Hacker in 1503

by his goodis which her is present in a plent of dett and demanndith of hym xiis. ster. which he awt and wrongfully withholdith for as moche as the xviith day of December (I502) he bought of the forsaid William Hacker Grene gynger comfetts, a payr of pyncers, boters hamer and alle in one a innyd ball of latyn [lateen], boxis of conserva and other merchandis, so the said Gillam awt cler xiis. ${ }^{20}$ 


\section{Medical Records of Dartmouth, 1425-1887}

In 1507, Thomas Philip, barber, rented a tenement from John Rede maior and his burgesses for an annual rental of $26 s .8 d .{ }^{21}$ This was a corner tenement with a garden, opposite the pillory. The desirability of a corner site for a doctor's house appears to be of some antiquity! In $15^{12}$, he served in a jury of twenty at the Mayor's Court. ${ }^{22}$

The records of these early barbers have been given in detail as they are of importance in assessing the status of early medical practitioners in a small borough. These barbers were citizens of consequence-one became mayor and one at least practised medicine as we know it today; they served on juries; they sued for recovery of debts. There is a strong inference that medicine was as much their stock in trade as hairdressing. It is significant that there is no record of a surgeon or apothecary or physician, and that only one leche is identifiable from the records.

\section{Leprosy}

There was no leper hospital in Dartmouth. Those who were suspected of suffering from leprosy were sent to the House of Lepers of St. Mary Magdalene at Totnes. This house was founded at a very early date, and is referred to frequently as a beneficiary in old wills. In the fifteenth century it evidently came under the control of the corporation, for in the parchment roll of the Totnes Mayor's Law Court dated I $44^{8-9}$ there is this entry:

That the Bretheren and Sisters of the House of Lepers of St. Mary Magdalene shall have one fire-hearth, and that in the hall; and that from henceforth they shall not have their fuel put in their own chambers; but fuel is to be brought into the hall where all the bretheren and sisters meet in turn.

In the following year it was ordered that every brother and sister, and leper, entering the House shall at the end of his life leave there in the custody of the wardens one bed, one platter, one pot, towards the support of the house and its chaplain, unless so poor as not to possess such goods. ${ }^{23}$

In 1546 , the hospital was described by Thomas Cromwells inspectors as:

For the relief of xi lazars and syche peple who have besyde theire mausyer house certyyn lands. There is abiding at this present in the hospitall 8 poor lazar peple which be more than the profytts of the lands belonging to thaforsayd hospital is able to susteyn. Notwithstanding, if any be brought, they be receyved untyll the said nomber of xi be fullye completed. The yerelye value of the lands and possessions $115 s .8 d .24$

In 1577 , the allowance to the lepers was $8 d$. a week each. ${ }^{25}$ in 1617 , there were six persons receiving the benefit of the charity. ${ }^{26}$ The records of the receiver of the Borough of Dartmouth for $1621-2$ show that it was still at that late date used as a leper hospital, for there was 'paid unto Christopher Brooking of Totnes for one year for William Mayne the lazar in the maudlen and his wife ended the I 3 th of October last past the sum of $£ 4$ I $5^{s}$. $4^{d}$.' (The rate has been increased to I $d$. per week each.) ${ }^{27}$ Further evidence that leprosy was still feared in the seventeenth century comes from a petition in the Totnes Corporation papers. 


\section{R. M. S. McConaghey}

One Nicholas Harris who had been for nearly forty years a foot postman in Totnes had been elected by the Corporation to one of the almshouses, but some enemy had informed the magistrates that he was a leper. Consequently he was stopped from taking up residence until he could show that he was not so infected. To obtain the evidence he travelled to London and presented himself at St. Bartholomew's Hospital praying for examination by the president and governors and surgeons of that hospital. The certificate which is appended to his petition reads:

We whose names are under written on this petition have viewed the body of the petitioner, and in our censures he is free from the imputed disease. Tho. Moundeford, Pres. Coll. Med. Lond., John Argent, Rich. Andrews, Sy. Baskerville, censors. Math. Gwynn, registrarius.

The reputation of the College of Physicians must have been considerable, and it is creditable that its most prominent members should append their signatures to the petition of so humble a supplicant. In 1640 , the receipts of the leper hospital were $£_{1} 8$ I 45 . O $\frac{1}{2} d$., and there appear to have been only two inmates. In 1660 , the receipts had dropped to $£_{17} 9$ s. 8d., and it was occupied by Edward Langworthy, his wife and children. After this date there are no further records of the charity, but the name of Magdalene Road still perpetuates its memory. ${ }^{28}$

\section{Tudor and Stuart Times}

Dartmouth was still a busy port, its ships trading to many distant places. Fine buildings, some but recently destroyed, some now rescued from decay, are evidence of the prosperity of the borough. Its steep and narrow streets and cargo-littered wharves were witness of much coming and going, and talk ran high of fabulous lands far off across the seas; seas themselves traversed by tall, Spanish galleons beating homewards laden with all the new-found wealth of the mysterious West. Sea traffic has its special dangers to health, and Dartmouth suffered from several epidemics and was responsible for their spread to other places. In 1586, gaol fever broke out in Exeter and was carried from there throughout the country by the justices and local gentry, who were wont to assemble in the shire capital at assize time. Then old friends would meet, cellars and wardrobes be replenished, gossip and news be exchanged, matches made, and all the stored-up business of the past year be completed. The assize itself with its pomp and circumstance was the main meeting place of all these petty justices. Crowded together in the small Guildhall, they were within crawling distance of the lice-infested prisoners. The assize over, they rode slowly home through the lanes and moorland tracks to their family seats, visiting friends and relatives as they passed along. As they rode they sickened. The epidemic, notable for its mortality amongst the rich rather than the poor, lasted about six months. It is described in graphic words by John Hooker of Exeter who was probably an eye witness. This, according to his account, is how it started:

... not long before, one Bernard Drake; Esquire (afterwards dubbed Knight) had been at the seas, and meeting with certaine Portingals, come from New-found-land and laden with 
fish, he took them as a prize, and brought them into Dartmouth haven, in England, and from thence they were sent, being in number about eight and thirtie persons, unto the goale of the castell of Exon, and there were cast into the deep pit and stinking dungeon.

These men had before [been] a long time at the seas, and had no change of apperall, not lain in bed, and now lieing upon the ground without succour or reliefe, were soon infected. . . .29

Little is known of the medical men of Dartmouth in Tudor times. The town fitted out, as its quota against the Armada, two ships, the Crescent manned by seventy men and the Harte with a compliment of thirty. Both carried a surgeon, who received $f_{1}$ a month for his services (the same wage as was paid to the mariner's mate and the trumpeter). An entry in the book of charges for fitting out the ships, runs: 'I/t payd to Pultron a badde surgeon for the Harte 02.00.00.' 30 But whether Pultron was a native of the town we do not know. In the early years of James I, I can find mention of only two medical men. William Lerfaite, Chirirgeon, is cited as living in a tenement between the lands of the Rowpe in 1601. ${ }^{31}$ Another surgeon, Thomas Garrett who died in 1608, was a Londoner of Aldersgate, and probably one of those travelling men who would go from place to place attending at the annual fairs. ${ }^{32}$ Perhaps it was William Lerfaite who in 1604 was responsible for these two sad entries in the St. Saviour's Parish Registers:

Osborne, Joane, w. of Henry who dying in travaile with child was ript and a man child taken out of her, was with her child buryed, 8th June.

Brynn, Ames, w. of Davye in the same lamentable order Dyed and being ript with her boy was buried, i ith June.

Efforts to get a living child after the death of the mother are not often recorded, and we probably owe our knowledge of these two cases to the difficulty that the parson experienced in accounting for the double burials.

Queen Elizabeth and her ministers maintained a tight hold on local affairs through the Privy Council. No detail of parochial administration was too small to escape its notice. When in 1598 a citizen threatened to pull the mayor's beard and was thrown into prison, the Privy Council were at once petitioned, and when Thomas Plumbleigh who had himself been mayor threw stones at the reigning dignitary, a warrant had to be obtained from the Lord Chief Justice. ${ }^{33}$ The Poor Law Act of 160 i imposed on the parishes the responsibility for the care of the poor, and the Privy Council saw that the offenders did their duty. In Dartmouth, however, the corporation still looked after their poor, and there are such entries as these in the receivers accounts: ${ }^{34}$

In December 1620. Paid to Mark Mayes child being sick, $1 /-$ and more was paid to her at several times the child being sick 2/a shroud for the child is $1 / 5 \frac{1}{2}$

To James Holes wife being sick 2/-

To George Coomes wife $6 d$.

In September 1621 . To Coomes wife 10 weeks at $12 d$. per week 10/-

To a woman that kept her $8 d$.

These payments were for subsistence and nursing only: there is no mention of any for medical treatment. 


\section{R. M. S. McConaghey}

\section{The Plague in Dartmouth}

The old registers of the church usually have marked after the name of the deceased his calling, if it was important. Though there are in the registers no records of surgeons domiciled in the town, there are several of midwives. 'Stone "old mother" a midwyfe' died in I590. So did another midwife Sydwell Philpe. I590 was a plague year in Dartmouth and in other towns in Devon. In the registers of St. Saviour's for that year there are the names of eleven whose entries are specifically marked with a $\mathbf{P}$ to signify that they were victims of the pestilence. Eight are so marked for the year after, and for the year before ( 1589 , the year after the great Armada) there were sixty deaths, and in $159^{\circ}$ there were forty-seven; this compares with a yearly average of thirty-one for ordinary years. We know that in 1590 the plague spread from Dartmouth to Totnes, for, in the parish registers there, there is an entry-'Margorie, the daughter of Mr. Wyke of Dartmouth, the first of the plague'-the first indeed of a death-roll which rose to a total of 246 during the next eight months. ${ }^{35}$

Other years of high mortality in Dartmouth were 1596 when fifty deaths occurred, and 1602 when twenty of the fifty-seven deaths recorded during the year occurred in July and August. In London, plague was prevalent in 1593 and $1603 .{ }^{36}$ After 16 Io plague was more or less absent from the country, although there is evidence of an outbreak in Sherborne in $1611 .^{37}$ There is, in Dartmouth records, a certificate dated 16 I 3 given by Sir George Speke and other justices of the peace for Somerset that

George Coxe, William Axol and William Crocker dwell at Wolmaston near Crewkerne where there is no sickness of the plague nor any suspicion thereof and that they may travel to Dartmouth to sell goods. ${ }^{38}$

This control of travellers was a permanent feature of life during those troublous times. If any were suspected of coming from a place infected by the plague they were at once stopped. Thus, in $164^{\circ}$ the town cryer was paid $4 d$. 'for crying about the sickness that none should entertain them' and a watchman was paid $6 d$. 'to watch for the coming of Mr. Clist who was doubted to come from Taunton a place infected'. ${ }^{39}$

The best recorded epidemic of plague in Dartmouth was that of 1627 . The Borough of Clifton Dartmouth Hardness comprises the three parishes, St. Saviour's, St. Petrox and Townstal. Of the church registers, we have only St. Saviour's to help us. Those of the years round about 1627 for both St. Petrox and Townstal are lost, or were never kept; but the average burials in each of these parishes for the years before and after are only a little less than those for the main church of the town. It would be safe at least to double the St. Saviour's numbers. The burials for the year in that parish rose to ninety-two, and of them it is estimated that fifty-six were due to plague - that would give us for the three parishes a plague death roll of $110-$ a not insignificant figure in a population of about 2,00o. If we break down the deaths in St. Saviour's by the months, we find that March, April, and May were averaging three to four death, but in June there was a sudden rise to seventeen (Fig. I). Looking into accounts of the 
Medical Records of Dartmouth, 1425-1887

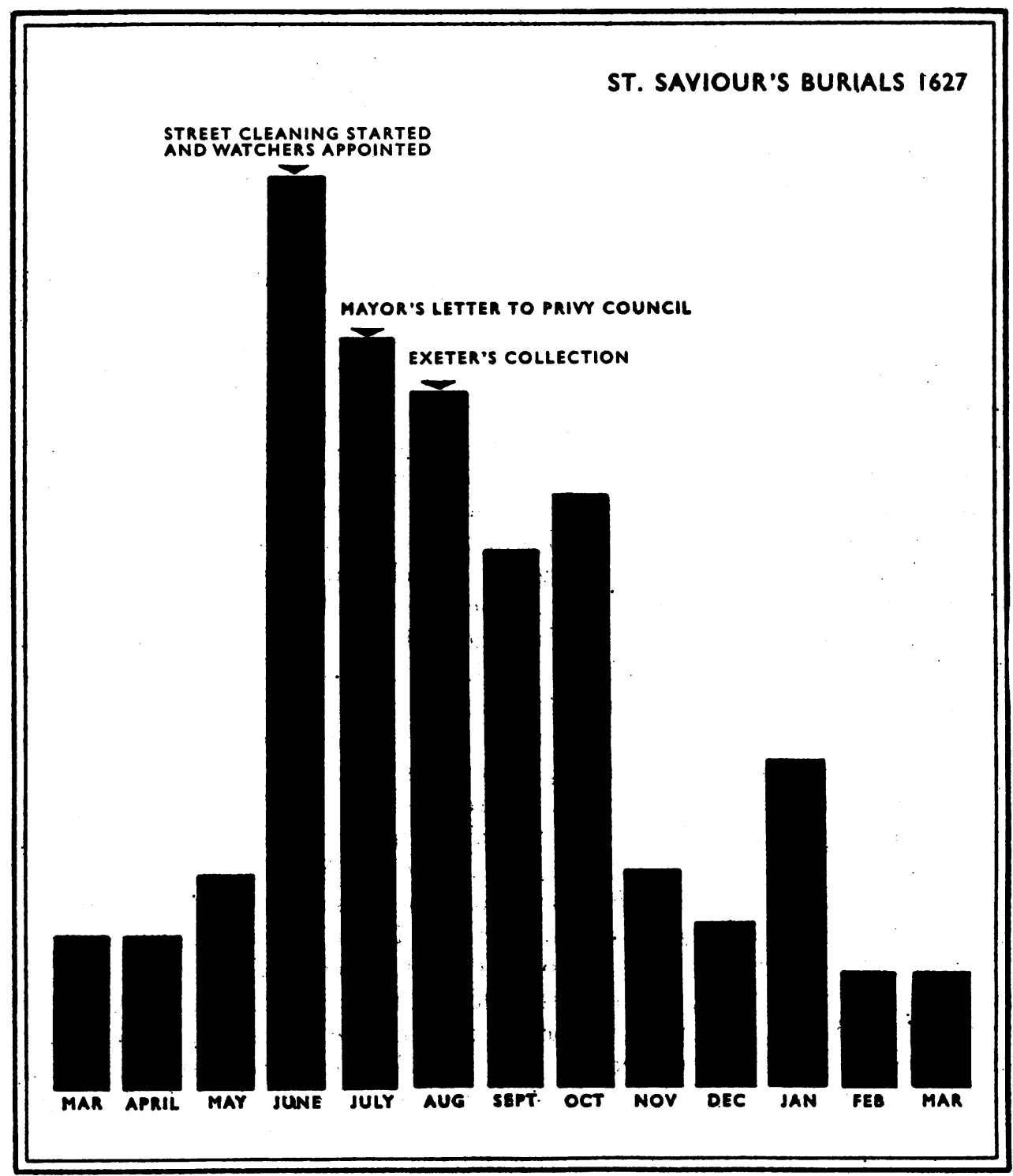

Fig. I.

Burials in St. Saviour's Parish, Dartmouth, in the Plague year of 1627 


\section{R. M. S. McConaghey}

borough we find the first reactions of the corporation to this calamity. On 2 I June the town cryer was paid $4 d$. for crying that the streets should be cleansed, and a shilling was expended on repairing two conduits. ${ }^{40}$ From 26 June watchers were employed. Their duty would be to see that those infected did not mingle with the rest of the population. The watchers cost the corporation $£ 9$ i $3^{s .} 9$ d.1 $^{41}$

On 29 June 1627 , it was reported to the Privy Council that the plague was so hot in Dartmouth that the inhabitants had left. On igth July the Mayor wrote to the Privy Council that it was true that the inhabitants were still away, but the plague had ceased; only fifteen houses had been infected, the inhabitants of which had all been removed to pest-houses remote from the town. ${ }^{42}$ In view of the events which followed this was a masterly understatement.

A 'house of ease' was constructed-the bill of costs for it is still extant; it was a wooden structure and, as the bill refers to 'and other work in Tounstal', the inference is that it was situated at the top of the town. ${ }^{48}$ There was, we know, a 'poor house' in Townstal as late as 1840 . Another document is concerning 'the monies expended on the poor in the Almshouse in the tyme of sickness' which amounted to $£_{22} 7 s$. od. ${ }^{44}$ Most of this money was paid to one Avis (or Ames) Coule. There is an entry 'pd for faggots, coal, clothing, beer, and for burying widdow Middleton (to Bearers) Many other entries are for shrouds, and one entry runs 'mo. pd. Thomas Forde for lime and tempering of it for washing of Tapeleyes and Lapthorne's howse: rs.' Limeing of the houses which were infected was a common and common-sense practice.

How were these disbursements met? So far as I have been able to ascertain there was little call on the poor rates, nor was a special rate levied, as happened in Plymouth and many other towns. Church collections at St. Saviour's raised two guineas; St. Petrox produced 8s. $5 \frac{1}{2} d$. and a further sum of $£ 5$ was received by the Mayor from an unspecified source. ${ }^{45}$ Robert Martin (perhaps he who had been mayor twenty-nine years previously, or his son) gave $£ 20$ to the poor this year. ${ }^{48}$ Thus a sum of $£_{28}$ os. $5 \frac{1}{2} d$. was raised in the town for distribution. In view of the letter sent by the mayor to the Privy Council on 19July stressing the smallness of the epidemic, it is interesting to find that a gift of $£ 3^{\circ} 15^{s} .5 \frac{1}{2} d$. was sent by John Tailor, Snr., then mayor of Exeter, on the 26 August, to the mayor of Dartmouth, being the proceeds of a collection for the poor of Dartmouth then afflicted with the plague. ${ }^{47} \mathrm{I}$ have been unable to trace the receipt of this money; it is not mentioned in the Receiver's accounts for this year. Such municipal and parochial gifts to towns afflicted with the plague were not uncommon. When, in 1665 , the last and greatest plague decimated London, Dartmouth sent $£ 20$ to its relief. ${ }^{48}$

\section{Poverty and Friendly Societies}

During the next 150 years the town remained static. Its population did not markedly increase; its revenues came from fishing in home waters, and from deep sea fishing off Newfoundland; wines were imported from France and Portugal. Geographically isolated from other centres, little internal progress 


\section{Medical Records of Dartmouth, $1425-1887$}

was made. Few records of medical men in the town can be found. John Lomer, Chireugeon, left property by his will dated $\mathrm{r} 734$ to his sister Elizabeth, wife of Robert Newman, a prominent merchant in the town; ${ }^{40}$ he must have been a man of standing, but there is no record of his practice. It is from the affairs of the poorer inhabitants that, as time went on, we can glimpse something of the work of the rural doctor.

In the last quarter of the eighteenth century, in common with other parts of the country, the Friendly Society movement began to arouse an interest in the inhabitants of the borough. The first, founded in 1776 , was specifically for tradesmen. ${ }^{50}$ In this, and in one or two other details, it presented unusual features. Its title was simply 'a friendly society held in the Town of Dartmouth for relief of the sick and for burying the Dead'. It was limited to 150 members, all to be tradesmen under the age of thirty at the time of admission; who could earn twelve shillings a week as journeymen of good repute. The society met monthly at the Seven Stars Inn. Each member had to pay $5^{s}$. to the stocks on entry, and rod. per month thereafter of which $2 d$. was spent-presumably on entertainment-at the monthly meetings. In sickness; if the member was confined to his room, he received $i s .6 d$. a day; if not so confined but unable to work Is.;

but [ran the rule] if such sick member's disorder be of a nature to require medical aid in such case he shall be allowed on producing a certificate from the Doctor that his charge had been full five shillings, Five shillings per week extra.

One of the diseases specifically excluded was gout-presumably it was felt that this disorder was self-inflicted. In the eighteenth century gout was universally regarded with suspicion: it is a disease not unfrequently met with in Dartmouth at the present day. The special provision made by this friendly society to contribute towards the fees of the medical practitioner was most unusual at this time, but another society in the town had a similar rule. The Carolinian Society of Women by its rules of 1827 allowed that 'Any Member who shall have received one week's bed pay may be visited by a Doctor if the Society shall think proper at the expense of the Society'.

The use of the term 'doctor' in these two documents is of great interest. It is generally thought that at this time the title was still retained only for those who held the doctorate in medicine or divinity of a university, and medical practitioners unless so qualified referred to themselves as surgeons, surgeon-apothecaries, apothecaries, or sometimes medical practitioners. ${ }^{51}$ Crabbe, the apothecary, never used the word to describe those of his calling, yet the poet Hood frequently uses it generically for all the fraternity:

In many a little country place

It is a very common case

To have but one residing doctor,

Whose practice rather seems to be

No practice but a rule of three,

Physician-surgeon-drug-decocter; . . .58

IOI 


\section{R. M. S. McConaghey}

There is no evidence that a physician with a doctor's degree was practising in the town at this time.

Altogether, records remain of five friendly societies for women. The 'Fifth Friendly Society for Women in the Borough of Dartmouth' held its meetings at the King's Arms Inn. It was limited to sixty members. A particular restriction in this club was that its members were not to receive benefit whilst with child or during the month of lying in, except for fever, when the time of sickness allowable for benefit was limited to one month.

How necessary these societies were for the protection of less wealthy people will be realized when it is remembered that the Poor Law Act of Elizabeth was still operative and the cruel Act of Settlement ( 1662 ) was rigorously enforced by the overseers. A manuscript, foolscap volume bearing the inscription 'The St. Saviour's Examination Book from the 12 th day of December 1819 to .... 1827 ' is still in the strong-box in that church. ${ }^{53}$ It gives an illuminating account of the fate of paupers in the years preceeding the Poor Law Amendment Act of 1834. In it the vigorous efforts of the parish officers to be rid of the burden of an illegitimate child are frequently described. There are twenty-two examinations for this. Each case had to be brought before the magistrates for examination, at the Petty Sessions. Usually there were two justices on the Bench, sometimes there was only one. If the pauper was too ill to attend at his examination one of the magistrates went to his house and took down his statement, and then certified on oath to his brother magistrate on the Bench that the pauper 'was unable to leave his bed through sickness to attend the petty sessions'. There is no mention throughout the book of a surgeon having given a certificate or examined a patient.

The cases in the book give a fascinating picture of the lives of the poor at this time. The first entry relates to Ann Reymurs who gave this account of herself; sixteen years since she had been removed by a 'Regular order of Removal' from St. Saviour's to the parish of St. Andrew's in Plymouth, she being 'with child of a Bastard Child'. Later she had returned to Dartmouth where she married an Hanovarian, who deserted her. She had then hired herself as a servant in the town together with her son. 'She had never done anything to gain a settlement to the best of her knowledge and Belief'. In cases of bastardy where the father was known, surety was taken from him if he was a person of substance, pending the birth of the child. When the baby was born he became the subject of filiation. The surety in one case was as high as $£_{20}$ from himself and $£_{10}$ from a relative; filiation was rated at $2 s$. a week and the cost of the summons, for which he had to pay was $7 \mathrm{s.} 6 \mathrm{~d}$. (This summons was delivered by an accountant whose name figures on the next page dated two days later for a similar offence.) Sometimes the expectant mother submitted herself to a voluntary examination. In another case maintenance at is. $6 d$. a week was charged with ' $6 d$. on the mother or suckle the child'. The expenses $(£ 2)$ of lying-in and a filiation order at $5 s$. were also claimed off the father.

The grounds for proving the place of settlement seem today slender. Betsy Norton was born in the parish of Malborough twelve miles away, but when she 


\section{Medical Records of Dartmouth, 1425-I887}

was very young her parents moved to St. Saviour's; at the age of seventeen she went to Guernsey and then to Jersey. She returned home pregnant and was removed to Malborough, the place of her birth, by the parish officer. Her father who was also examined was a native of Blackawton, five miles distant, and had moved to Salcombe in the parish of Malborough to work at his trade as a blacksmith. Because he had rented premises there for two years, during which time his daughter was born, the poor girl was sent back to a place where she can have had no friends, at a time when she would most have needed their help. The Act of Settlement was indeed responsible for some of the high mortality amongst infants in the eighteenth century. Married women and widows were sent to the place of settlement of their husbands. Jane Grimes was born in St. Saviour's parish, and married William Grimes in Plymouth. He was a 'native of and belonged to the Isle of Wight', but Jane had never heard him mention in what parish. The churchwarden therefore made the journey to the Isle of Wight, sought out the husband's mother whom he found to be in receipt of parish relief in New Church, and thus proved the place of settlement of the pauper who had then to go to a place to which she had never before been.

The parish officers got the children under their care off their hands as early as possible by apprenticing them. Eight years old was none too young! One, William Blenchard, was bound to a shipowner at that age, and lived aboard ship until his apprenticeship expired. This was usually at the age of twenty-one. The old system of servants hiring themselves by the year was still prevalent, and we read of yearly wages of $£_{3}$ and $£ 4$, and of weekly wages of $2 s .6 d$.

As one would expect in a seafaring town many of the cases dealt with concerned sailors, their wives and sweethearts. The most pathetic story in all the book concerns Margaret Robetelle, otherwise Winsland. Born in Quebec, at the age of eleven she hired herself as a servant till at the age of eighteen she married William Winsland, a mariner, in the service of her master. Three days after their marriage they sailed for England in a vessel in which Winsland had engaged himself to work as a mariner. The ship touched at Lisbon on her way home, and Winsland had the misfortune to be pressed into His Majesty's service and to be carried on board the Beagle. Margaret, however, on producing her certificate of marriage was permitted to stay on board the sloop with him for eighteen months, when Winsland was taken ill and sent to the hospital at Gibraltar where he remained till his recovery. He was then posted to the Hercules in which he served about three and a half years, Margaret living with him as his wife the whole time. When the Hercules reached Portsmouth, Winsland got leave of absence; Margaret stayed behind. About a fortnight later, she received a letter from him saying that when he came back he would bring his first wife with him. For two months Margaret waited, but neither Winsland nor the other wife appeared. Her shipmates, the crew of the Hercules made a collection for her so that she might travel to Deptford to procure a passage back to Quebec, but this she was unable to get, not having enough money to pay for her passage. So she got work and maintained herself for eighteen months, after 


\section{R. M. S. McConaghey}

which time Winsland, now in the coasting trade, returned to her, and lived with her whenever his ship was in London. Two years before the time of the examination he told her that his first wife had died, and said that she had better go to Dartmouth where his parish was. Again deserted, she worked awhile in London, and then in Portsmouth before arriving in Dartmouth to throw herself on the tender mercies of the overseers of the poor.

Such were the types of person that the doctors of the time may have been called upon to treat. Poverty was rife. It is probable that the parishes or the town paid something towards the treatment of these people. Stoke Fleming whose boundaries ran at that time almost into Dartmouth paid one of the Dartmouth practitioners, Dr. John Puddicombe, for treating their poor, but there is no evidence of the fees paid in the town. ${ }^{54}$

\section{The Poor Law Amendment Act 1834}

The New Poor Law, as it came to be called, was in the main a consolidation of the various measures which had been passed since the Poor Law of Elizabeth (1601). The chief reform was to unite groups of parishes into unions administered by guardians, and to appoint relieving officers to carry out their orders. Each union was to appoint medical officers to the several districts under their control. The Act of 43 Elizabeth had made no provision for medical relief of the poor. One or two Acts in the early years of George III gave the justices some power of ordering medical relief to the inmates of workhouses. The practice of giving medical relief systematically arose in the later part of the eighteenth century and parishes in the south, east and centre of England then began to appoint medical officers regularly.

Under the new Act, Dartmouth was placed in the union of Totnes situated about ten miles up the river. The diagram opposite (Fig. 2) shows the extent of the area served by the Totnes guardians.

To get some idea of the nature of this area, it must be borne in mind that the parishes of St. Petrox and St. Saviour's lie on the shores of the deep estuary of the Dart with Kingswear and Brixham across the river. The third parish of Dartmouth-Townstal-rises to 500 feet above the rest of the town. From Dartmouth to Totnes, deep valleys intersect the fertile agricultural land, which for the most part is highly cultivated from countless small farmsteads lying in the hollows. North of Totnes the land rises again to Buckfastleigh and Holne, deep in the moars. Before the amending Act of 1834 , there were estimated to be 3,000 paupers in this area. In 1844 the number was said to be 2,400 . The union was served by thirteen medical officers, whose combined salaries before the Act had amounted to $£ 268$ exclusive of extras: In $1841, £_{3} 16$ I4s. od.; in 1843 , $£ 281$ rgs. od.; and in $1844, £ 307 .{ }^{55}$ The reason for the fluctuation was the practice of the guardians of putting these appointments out to tender annually, and the average increase over the pre-Act figure was due to extras being omitted. A committee of the House of Commons appointed in 1834 to enquire into the operation of the Poor Law Amendment Act had recognized the evil of 


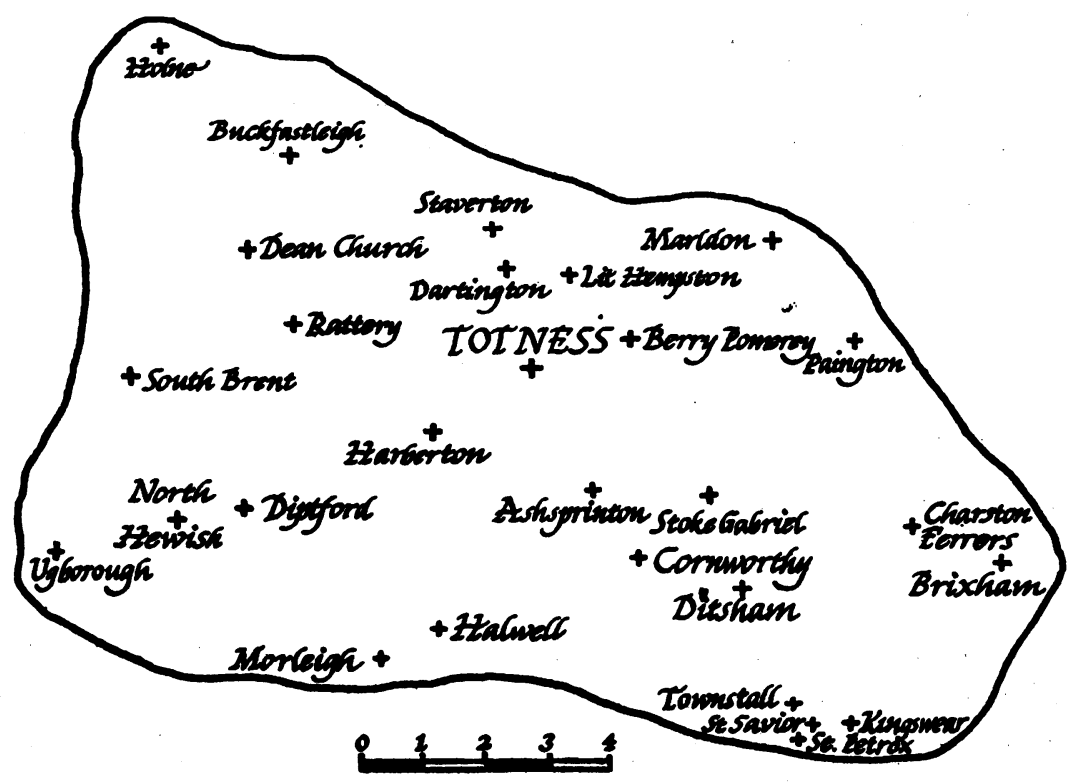

Fig. 2.

Area served by the Totnes Guardians

From Report of the Select Committee on Medical Poor Relief, p. 845

advertising for tenders from the medical profession and had reported to this effect. The committee considered

it to be most important that the poor should be perfectly satisfied with their medical attendants; and ... it appears to be desirable, as indeed is almost always the case, that the care of the poor should be confided to the same person who is in the habit of visiting their richer neighbours. ${ }^{56}$

The difficulties in the administration of medical poor relief were many, and complaints were received from all over the country. The government of the day reacted by appointing a parliamentary committee under the chairmanship of Lord Ashley (afterwards Lord Shaftesbury), which proceeded to take evidence from unions. So difficult did it find the work of sifting evidence that the reports of the committee were laid before parliament without comment. The affairs of the Totnes guardians are a good example of the state of affairs generally. The poor law commissioners were three in number. Their indefatigable secretary was Edwin Chadwick, a philanthropist of the school of Bentham with a genius for administration. In his struggle to improve the health and living conditions of the people, he let nothing stand in his way. He was a man of few other sympathies and held the doctors in little respect; however, in the struggle which they had with the Totnes board of guardians, he did see that they had a fair deal. Trouble started when the commissioners received a handbill which had been 


\section{R. M. S. McConaghey}

circulated by the guardians requesting applications from persons desirous of being appointed as medical officers for the union for the ensuing year. The commissioners immediately wrote for an explanation. The guardians replied giving a list of the appointments made, and the salaries attaching to each, together with a statement of the salaries in the preceeding year. Those relating to Dartmouth practitioners are listed. ${ }^{57}$

\begin{tabular}{|llll|}
\hline \multicolumn{1}{|c}{ PARISH } & \multicolumn{1}{c}{ sURGEON } & \multicolumn{1}{c|}{1844} & \multicolumn{1}{c|}{1843} \\
\hline Dittisham & Mr. Burroughs & $£$ 10 per annum & \\
Kingswear & Mr. Paige & $£ 4$ per annum & $£ 3$ per annum \\
St. Petrox & Mr. Puddicombe & $£ 4$ ros. per annum & $£ 4$ per annum \\
St. Saviour's & Mr. Paige & $£ 8$ per annum & $£ 7$ per annum \\
Tounstal & Mr. Puddicombe & $£ 7$ per annum & $£ 6$ per annum \\
\hline
\end{tabular}

The difference in the salaries was due not to any increase in work but to the elimination of extras. The surgeons appointed had 'to supply the requisite medicines, and surgical appliances (trusses only excepted)'. The agreements with the medical officers were subject to notice of twenty-eight days at any time. ${ }^{58}$ The clerk of the board wrote:

the board in making their appointments have deviated from the regulations laid down by the Commissioners respecting extra charges, in consequence of the unpleasant and constant disputes in which the board has at various times become involved with some of their medical officers respecting these charges, and the almost certainty of, at no distant period being involved in these disputes with the whole of the medical officers of the union; a thing, if possible to be avoided.

As the appointments had already been entered into the board begged that the commissioners would sanction them. This the commissioners refused to do. They sent an assistant commissioner to meet the board and enquire into their complaints. His report is full of interesting details about medical practice in the area. ${ }^{59}$ Representations were made to him that the charges for extras prescribed in the commissioners' order were greater than those usually paid by independent persons to doctors in the neighbourhood, and that this had influenced the giving of poor relief orders to persons not entitled. The assistant commissioners referred to what he had been told by a physician in another part of the county:

The Bideford Board, when I last attended that union complained to me that persons were made paupers for the sake of high fees; and thus, in six months, they had to pay $49 l$ for fractures alone. They did not mean that persons got fractures for the good of the medical men; but that persons having fractures were made paupers, who otherwise would not have been so, for the sake of the high fees.

The evil had only developed in the Totnes union in any marked way in the last six months, and then only in parts of the union. The Brixham medical officer had doubled his salary by means of extra fees for which he obtained $£ 12$ I 5 s. od., 


\section{Medical Records of Dartmouth, 1425-1887}

his salary being only $£_{12}$ Ios. od. So had the medical officer at Stoke Gabriel. Many of the overseers were unable to read or write, being small farmers of $£_{10}$ or $£_{20}$ yearly rental, and thus-so said the guardians-were persons incapable of exercising the necessary discretion as to when and to whom they should give orders for medical attendance, and they were constantly giving orders for cases which were not urgent; these should have been given by the relieving officers only. This led to strife, the guardians objected, the overseers appealed to the magistrates, and the appeal was often allowed. All this, the guardians said, led to ill-feeling. These two factors, the low fees usually paid to the medical men, and the illiteracy of the overseers were held by the assistant commissioner to be points which distinguished the district from other parts of England. The arguments which arose with the doctors about claims for extras are described as 'disgusting and indecent discussions'. Turning to midwifery, the assistant commissioner wrote

In this part of England the custom, that has I believe been superseded in most others, still exists of employing female midwives at very low rates of payment, the superior classes even adhering to this practice. ... The guardians declare that the overseers are continually giving orders for the doctor to attend the patient, who has a fee of $10 s$. or $\mathrm{I} l$, when in the instance, as in nearly every independent case a midwife with a fee of $2 s .6 d$. or $5 s$. would suffice. ${ }^{60}$

The commissioners stuck to their orders-indeed, they declared that without the consent of the Secretary of State they were unable to vary them-and the guardians of the Totnes union were forced to draw up fresh contracts with the doctors. In the opposition of the doctors to the guardians we can trace the beginning of collective action, and, although it is not named, the influence of the newly-formed Provincial Medical and Surgical Association is obvious. Jasper Parrott the chairman of the Totnes board of guardians, said

there was an understanding between the greater part of the medical officers, a combination in fact among them, that unless they could have certain prices, they would not agree with the guardians, and the consequence was, of course, that the guardians found it necessary to endeavour to introduce competition.

The Parliamentary Select Committee considered all these matters, and numerous doctors, and other administrators of the Poor Law were called up from the Totnes union for examination. A spokesman for the doctors was William Wills, described as 'medical man', of Totnes, who gave evidence that their pay was worse since the formation of the union; the salaries were much the same, but there were less extras. The labour had increased and there were consequently increased responsibilities. When the board had advertised vacancies without extras all but three of the medical men had accepted. The board of guardians then appointed a 'stranger' over the three defaulters at a salary of $£ 93$. The stranger kept a horse and had a seven mile round. In 1836 , a man with no qualification whatever was appointed to an extensive district in the union. When a pauper required medical attention he had first, unless the 


\section{R. M. S. McConaghey}

case was urgent, to obtain an order from the relieving officer. The greatest distance he might have to travel for this was six miles and six miles back to the doctor and seven miles again to his home. ${ }^{61}$

The chairman of the board of guardians in defending his colleagues tried to run down the characters of the doctors. He was able, amongst other allegations, to produce evidence suggesting malpractice by one of the Dartmouth practitioners. The letter he sent to the committee ran: ${ }^{62}$

... that he (the doctor) never used a pulley or any other instrument to replace the dislocated bone; that he neither gave him any kind of lotion to strike it with, nor did he give any medicine; that he only felt the thigh, and I think said attended him but once. . . . Again, in the parish of _ I am informed that the same medical man was called in to a case of midwifery, and attended it for a week or a fortnight, and then finding the woman incapable of paying the amount incurred, applied to the overseer of that parish for an order, and this was given - and he charged the parish $2 l$. for his attendance, and the board of guardians at Totness, I am informed disallowed $i l$. of this charge.

The surgeon who attended this patient was John Morgan Puddicombe who was either in partnership with or assistant to his father. He had studied at St. Bartholomew's and achieved his M.R.C.S. in 1837 and his L.S.A. in 1838 , and was thus a fully qualified medical practitioner according to the conditions prevailing before 1858 . He was also the coroner for the borough. The Select Committee called him to London to give evidence. They also called the pauper, and had him examined by a specialist before the hearing. The evidence of Puddicombe gives an intriguing picture of the methods of practice in those days. The pauper, Brewer, had met with his injury in the middle of the night.

The noise he made alarmed a gentleman living near the spot. On finding what had occurred and that the man was unable to move, owing to a fall from a considerable height, he ran to the nearest surgeon, and soon returned with my brother, a young man now serving his apprenticeship with my father, the latter being indisposed, and not able to attend. Finding themselves insufficient to remove him to a place of safety, they, with some difficulty, in consequence of the lateness of the hour, obtained the assistance of two men, and carried him to the poorhouse, in the parish of Townstal, where he was placed on a kind of bed, and left until morning when I was sent for to attend him; on my arrival I found a considerable shortening of the left leg, with the foot turned over the right tibia, at about the commencement of the lower third; combined with this was tremendous swelling of the muscles about the hip and thigh, so much so, that at my first visit the cause appeared so intricate and the pain the man suffered so intense, that I hardly knew how to act; I remained with him about twenty minutes, and after making gentle extension for a short time, the foot suddenly resumed its natural position; at this time the hip and thigh were at least double their natural size, and still remained so after this operation. On my next visit I found still considerable swelling and pain, which continued for many weeks; the patient was unable to move from the position in which he was placed.

In his perplexity, John Morgan Puddicombe held a consultation with Mr. Paige another surgeon in the town.

I told this gentleman (of course, confidentially) that I was doubtful as to the nature of the original injury. Mr. Paige and myself, with the assistance of the two overseers of the parish, 


\section{Medical Records of Dartmouth, 1425-1887}

with considerable difficulty removed him from the bed to a chair placed beside it, his bed was then made up for the first time since the accident, and he returned to it after remaining out a short time. About three weeks after this I stated he might be safely removed to the union house.

He was then lost sight of by Puddicombe. The patient was stated to be a poor, debilitated creature, without a home, who was long before, at the time of the accident and since his discharge, in the habit of sleeping in lime kilns and haylofts; a fall from the latter being the cause of the accident. By occupation he was a porter on the quay but employment was very slack and he sometimes earned a penny a day. To attend the inquiry, Puddicombe spent two days in London. The cost of the 200-mile journey was $£ 76 s$. od. and his expenses were $£ 44 s$. od. The patient's travelling expenses were $£^{2}$ and his subsistance Ios. $^{63}$ John Morgan Puddicombe became an influential and respected citizen of Dartmouth; he was three times mayor and was elected alderman. His practice continued in the family through his daughter, who married his partner, until the last of the line died in 1919 during the influenza epidemic of that year.

In I850, six surgeons lived in the town, the population of which was 3,000; today the population is doubled and there are four practitioners. White's Devonshire, a directory which was first published in 1850 and again in 1878 gives an interesting comparison. ${ }^{64}$ In the first issue none of the medical men thought it necessary to show their qualifications; in the second they all did so. Such was the effect of the Medical Act of 1858 , twenty years after which we find John Morgan Puddicombe still in practice and an alderman of the town. Samuel Elliot, another surgeon, was a councillor. R. Soper, in practice with Puddicombe, was a M.R.G.S. and L.S.A., and John Cowper was a doctor of medicine. Twelve years later, we find two other holders of the M.D., in Francis Davson, a magistrate whose son became the leading solicitor of the town, and Stephen Goodfellow, a borough councillor. In I887, the Cottage Hospital was established -in one of the old houses on the waterfront.

So ends the story of medical practice in this small town. It is a record doubtless little different to that of countless other country places, but in the telling a picture emerges of the progress of medical care down the years that gains much from its parochial flavour.

Throughout the centuries we find the doctor, whether he be known as a barber, a chirugeon, a medical gentleman, or a general practitioner, occupying a responsible position in the community in which he worked. In this short sketch we have been able to do little more than paint the high-lights, showing him in the environment in which he lived and describing some of the problems with which he had to contend. From the archives of other towns different lights and shades would emerge and thus in time a composite picture of the family doctor worthy of the subject will be painted.

Those that we have written of are such as were described by Sir John Simon in 1857 as men

whose lives are continuous acts of unrewarded devotion; whose distinterested goodness conduces, equally with the achievements of the great masters, to enoble the medical profession. ${ }^{65}$ 


\section{R. M. S. McConaghey}

\section{NOTES AND REFERENCES}

1. Prince, J., Worthies of Devon, 2nd Ed., 1810, p. 477.

2. Coulton, G. G., Medieval Panorama, Cambridge, 1938, p. 447.

3. Watxin, H. R., Dartmouth; i, Pre-Reformation. Parochial Histories of Devonshire, No. 5: The Devonshire Association 1935, 94.

4. Ibid, P. 940

5. Ibid., P. 213

6. Ibid., p. 112

7. Ibid., p. 113

8. Ibid., p. 393.

9. Ibid., p. 107.

10. Ibid., p. 118.

11. Ibid., p. 396.

12. Ibid, Pp 98, $101 \mathrm{ff}$.

13. Ibid., pp. 203 ff.

14. Ibid., p. 205.

15. Ibid., p. 222

16. Ibid.; p. 22\%.

17. Ibid., p. 229

17a. Ibid. p. 216

18. Bbid., p. 214

19. Ibid., p. 216

20. Ibid., p. 219.

21. Ibid., p. 165 .

22. Boid., p. 258.

23. WATkin, H. R., The Hietory of Totnes Priory and Medieval Toun, Torquay 1914-17, I, 527.

24. Trans. Devon Assoc., 1880, xII, 459.

25. WATKIN: Totnes. 1, 460.

26. Trans. Deoon Assoc., 1880, Xn, 463.

27. Dartmouth Corporation Records.

28. Trans. Devon Assoc., 1880, xII, 463.

29. HoOxzR, Johx, quoted by Creighton, A History of Epidemics in Britain, $1891-4,1,386 \mathrm{ff}$.

30. Trans. Davon Assoc., 1909, XII, 313 .

31. The archives of the Newman family. I am indebted to Sir Ralph Newman, Bart., of Blackpool House, near Dartmouth for providing me with this information.

32. The St. Saviour's Parish Register for Burials.

33. Trans. Deoon Assoc., $191 \mathrm{I}, \mathrm{Kum}, 147$

34. Dartmouth Corporation Records. D.D.62038/B.

35. Trans. Devon Assoc., $1880, \mathrm{xI}, 167$.

36. Wilson, F. P., The Plague in Shakespeare's London, Oxford, 1927.

37. Grerghton, C., A History of Epidemics in Britain, 1891-4, I, 501.

38. Dartmouth Corporation Records. D.D.61847.

39. Ibid, D.D.62684.

40. Ibid., D.D.62977.

41. Ibid., D.D.62276.

42. Greighton, loc. cit.

43. Dartmouth Corporation Records, D.D.62278/B.

44. Ibid., D.D.62278/A.

45. Ibid., D.D.62256.

46. Trans. Devon Assoc., $1911, \mathrm{xum}, 147$.

47. Dartmouth Corporation Records. 


\section{Medical Records of Dartmouth, 1425-1887}

48. Bell, Walter G., The Great Plague in London in 1665, revised edition 1951. London, p. 287.

49. Copy of Will, the property of Mr. John Burgoine of Dartmouth.

50. The Dartmouth Corporation Records contain a collection of these.

51. Graham, George, Lancet, 1957, I, 264.

52. The Complete Poetical Works of Thomas Hood, Oxford, 1920, p. 86.

53. I am indebted to the Rev. Roger T. Urwin, Vicar of Dartmouth, for permitting me to see this document.

54. Scott-Tucker, J. H., Parish of Stoke Fleming, 1953, Exeter, p. 42. 'I undertake the Medical Charge of All the Poor of Stoke Fleming, from four miles from the Parish Church, for Eight Guineas a year-Midwifery and Surgery to be paid for separately. John Puddicombe.'

55. The Third Report of the Select Committee appointed to Inquire into the Mode of Administering Medical Relief to the Sick Poor under the provisions of the Poor Law Amendment Act. Evidence of Jaspar Parrott, para. 5097, p. 339.

56. Ibid., p. I.

57. Ibid., p. 843 .

58. Ibid., pp. $845-6$.

59. Ibid., p. 846 .

6o. Ibid.

6r. Ibid., para. $4888:$ p. 328.

62. Ibid., p. 348 .

63. Ibid., para. 7681 : p. 459.

64. White's Devonshire. Edition 1850 and 1878 , Exeter, entries for Dartmouth.

65. Simon, John, Public Health Reports. Edited for the Royal Sanitary Institute of Great Britain by E. Seaton. London, 1887, 1, 289.

\section{ACKNOWLEDGMENTS}

Dartmouth Corporation records are under permanent loan to the Exeter City Library and are referred to here under their code letters D.D. I am indebted to Miss Marjorie M. Sparkes, B.A., the City Archivist, for her generous help in deciphering some of these documents. 